\title{
Are Indonesia contractors ready to implement last planner system? - an early investigation
}

\author{
Jati Utomo Dwi Hatmoko ${ }^{1, *}$, Human Adi Darmawan ${ }^{1}$, Zuldi Sabrian $^{1}$, and Mochamad \\ Agung Wibowo ${ }^{1}$ \\ ${ }^{1}$ Civil Engineering Department, Diponegoro University, Semarang, Indonesia
}

\begin{abstract}
Last Planner System (LPS) is one of Lean Construction's tools for scheduling to enhance project's reliability, productivity, and performance. It has already been widely adopted in many developed countries and shown benefits, such as shorter duration, less rework, and better communication. Despite its benefits, the use of LPS is almost unheard of in Indonesian. The aim of this exploratory research is to investigate the readiness of LPS implementation for Indonesia's projects. The assessment is based on five principles of LPS, i.e. Master Schedule, Pull Planning, Making Work Ready, Weekly Work Plan, and Learning, using four categories of assessment, i.e. not aware, aware, willing, and implemented. The levels of readiness are categorised into none, poor, moderate, high and excellent. Data was collected by interviews and questionnaire surveys with project managers and observations of four construction projects. The results show that on average the readiness level is moderate, particularly for Pull Planning and Look-ahead Plan. The main challenges identified include lack of confidence and resistance to change. These research findings provide an initial understanding of LPS as perceived by contractors, and later can be used as inputs to build a strategic framework to enable wider LPS adoption to improve Indonesia's project performance.
\end{abstract}

\section{Introduction}

The construction industry has been beset with common problems, which in turn may hamper productivity, such as waiting, material handling, overproduction, inventories, rework, and movement of workers [1]. These problems are mainly due to a lack of control of production activities during the construction phase, which eventually may cause project delays and cost overrun.

In 1999, Ballard developed a production system for construction projects adopted from production management of Toyota, called Last Planner System (LPS) which is part of Lean Construction (LC) [2, 3]. LPS is a management system that provides production control in scheduling to help increase reliability of scheduling system in order to increase performance and productivity significantly [4-6,7]. The implementation of LPS in construction projects in developed countries has shown a lot of benefits, such as increasing

\footnotetext{
*Corresponding author: jati.hatmoko@ft.undip.ac.id
} 
reliability of schedule [8-10], optimizing duration of production activities [9,11], eliminating wastes, and also reducing construction cost, rework, and defects [12]. Furthermore, LPS also invites all project's stakeholders to evaluate the schedule, so they can learn and create an effective schedule for a project $[4,13]$.

In Indonesia, LPS implementation is almost unheard of. In general, projects in Indonesia still use the conventional management system, as reflected by the use of traditional scheduling tools, such as bar charts, critical path method, and precedence diagram method [14]. The conventional system basically does project activities merely based on the initial schedule, without noticing the readiness and situation of the activities, which is known as 'push planning' [15]. This conventional management system is considered no longer sufficient in terms of showing future activities, and no production control [16], which potentially could jeopardise the project completion.

Learning from benefits gained by developed countries, LPS is seen to give positive impacts on Indonesian projects if implemented properly. Prior to the implementation, exploration on how contractors may perceive LPS for their projects is prominent as an initial step. This exploratory research aims to investigate readiness towards LPS implementation for projects in Indonesia. The objectives are; to build criteria for LPS readiness assessment, to identify challenges, and to recommend implementation strategy.

\section{Last planner system}

\subsection{The principles and steps}

One of the problems of the conventional scheduling method is that it does not have a system to control production activities [16], which in turn gives no value to activities in the project, and could end up as waste. LPS, on the other hand, allows activities in a project to match with the initial schedule by adding production system in the project. Project scheduling using LPS is done collaboratively with all project's stakeholders, i.e. contractors, sub contractors, suppliers, client, supervision consultant, including labours [11, 17].

Figure 1 shows LPS' principles and cycle. LPS basically consists of 4 levels, i.e. Should, Can, Will, and Did. 'Should' specifies what activities should be done, when, and by whom. 'Can' refers to making scheduled tasks ready, i.e. (the necessary materials are at hand, previous activities are completed and the workforce is available) [18], hence they can be performed as scheduled. 'Will' ensures what activities will be done in the planned period. 'Did' evaluates completed activities by all stakeholders, and compares them to the weekly schedule to identify failures [4, 7, 13, 19].

'Should' is the front end plan of LPS which consists of 2 elements, i.e. master planning and pull planning (Table 1). Master planning represents the start and finish of the project (master schedule), duration (milestone), and workflow (establishes promises). Pull planning optimizes the duration of activities by developing a phased schedule (PS), working collaboratively involved owner, subcontractor, and supplier (collaborative plan) which aims to obtain detail transition between activities (focus on handoff). 'Can' is the second phase of LPS by analysing, selecting, sequencing, and sizing (screening) activities which are ready to be done (look-ahead plan), then removing any constraints and preparing materials and tools for selected activities (making work ready). 

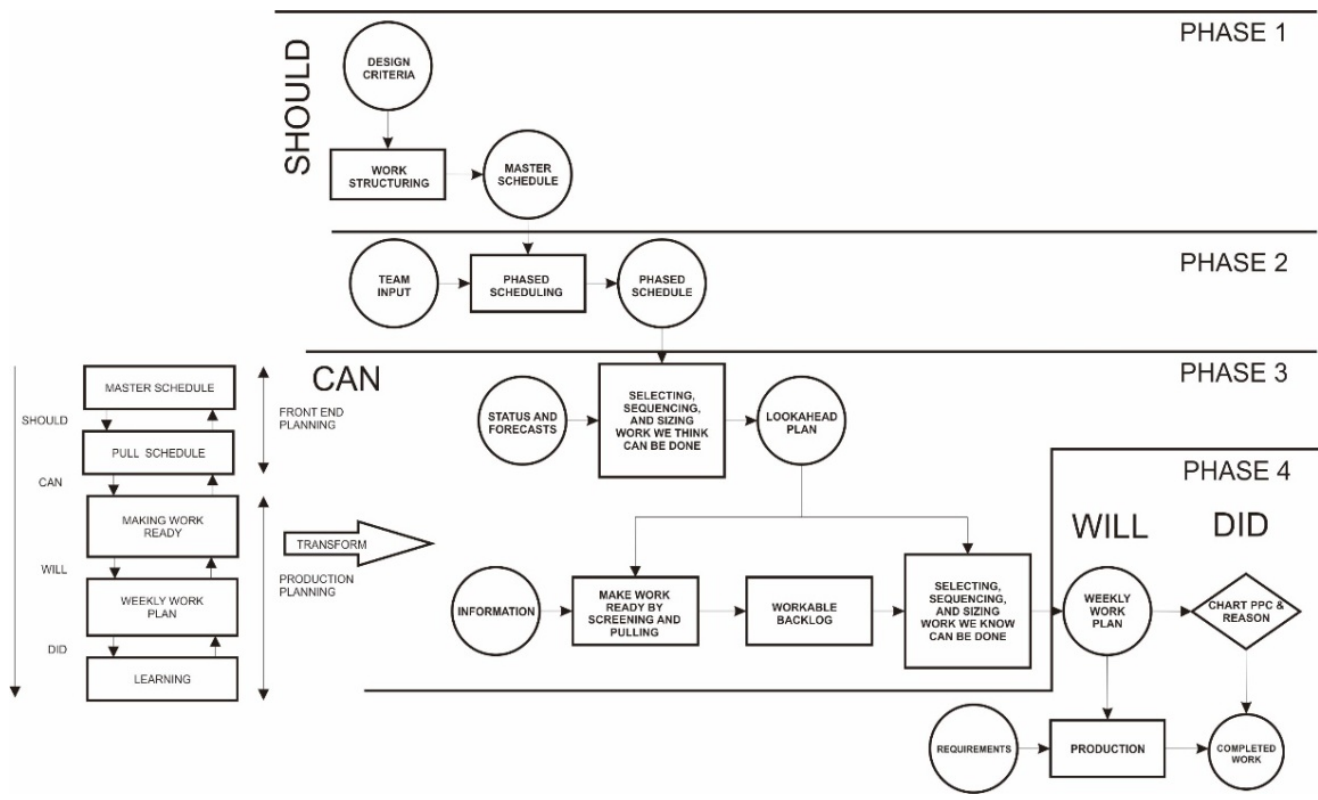

Fig. 1. LPS principles and steps [4], [7].

Later these activities are included in the weekly work plan (for priority activities) and workable backlog (for non priority).'Will' as the third phase consists of weekly work plan (WWP) based on work that is ready to be done in a certain time (reliable promises) to transform what 'Should' be done into what 'Can' be done [18], followed by a production session. 'Did' is the last phase of LPS by conducting daily coordination to provide information of WWP, evaluating plan completed in percentage (PPC) by comparing completed tasks to weekly schedule, and analysing problems as lessons for the following week (rapid learning). LPS also have two additional performance measures, i.e. Assignment Made Ready (AMR) and Assignments Anticipated (AA). AMR is obtained by dividing completed assignments that appear in the first week and next week to the number of assignments planned in the next week, while AA is obtained by dividing the number of assignments between the first week and next week to the number of assignments planned in the first week.

Table 1. Levels, elements, and indicators in last planner system [4, 19].

\begin{tabular}{|c|c|c|}
\hline Level & Element & Indicator \\
\hline \multirow{6}{*}{$\begin{array}{l}\text { Should } \\
\text { First step that Last Planner } \\
\text { Should do in running the } \\
\text { project as front end plan. }\end{array}$} & \multirow{3}{*}{$\begin{array}{c}\text { Master Planning } \\
\text { (Initial schedule of project) }\end{array}$} & Milestones \\
\hline & & Master Schedule \\
\hline & & Establishes Promises \\
\hline & \multirow{3}{*}{$\begin{array}{c}\text { Pull Planning } \\
\text { (Optimizing the initial schedule) }\end{array}$} & Phase Schedule \\
\hline & & Collaborative Planning \\
\hline & & Focus on Handoff \\
\hline \multirow{2}{*}{$\begin{array}{c}\text { Can } \\
\text { Finding activities that can } \\
\text { be done }\end{array}$} & \multirow[b]{2}{*}{$\begin{array}{l}\text { Make Work Ready Plan (MWRP) } \\
\text { (Preparing activities that can be done) }\end{array}$} & Look-Ahead Plan \\
\hline & & Make Work Ready \\
\hline \multirow{2}{*}{$\begin{array}{c}\text { Will } \\
\text { Step of determining } \\
\text { activities will be done }\end{array}$} & \multirow{2}{*}{$\begin{array}{c}\text { Weekly Work Planning (WWP) } \\
\text { (schedule based on activities that ready to } \\
\text { be done per week) }\end{array}$} & Weekly Work Plan (WWP) \\
\hline & & Reliable Promise \\
\hline \multirow{2}{*}{$\begin{array}{c}\text { Did } \\
\text { Step of assessing the result } \\
\text { of work }\end{array}$} & \multirow[b]{2}{*}{$\begin{array}{c}\text { Learning } \\
\text { (part of learning the result of schedule) }\end{array}$} & Daily Coordination \\
\hline & & \begin{tabular}{|l|} 
Percent Plan Complete (PPC) \\
Rapid Learning
\end{tabular} \\
\hline
\end{tabular}




\subsection{Last planner system implementation}

LPS has successfully provided advantages to many projects worldwide and has helped those projects become more cost-efficient and gain better performance. For example, the implementation of LPS at Sutter Health Fairfield Medical Office project, USA saved 15\% of total costs and achieved the completion date without compromising the quality even though there was a three-month delay. Other intangible benefits include the project becoming more solid, the labourers were getting used to 'learning with action' concept, and also increased trust among all stakeholders [20]. Another example, implementation of LPS in Arlington University project, Texas enhanced Percent Plan Completed (PPC) from 40$60 \%$ to $70 \%$ with $84 \%$ of peak point [6]. LPS implementation in Saudi Arabia revealed the same benefit. The PPC increased from $69 \%$ to $80 \%$ on average with a peak point of $86 \%$ at the first project. For the second project, PPC increased from $56 \%$ to $80 \%$ on average with a peak point of $84 \%$ for the second project [8]. Another research about LPS in Saudi Arabia also shows that LPS gave tons of benefits such as increasing productivity, reducing duration, and better HSE [21]. LPS implementation can also boost social interaction of all stakeholders, such as increased confidence, problem-solving ability, and increasing interaction and sharing information about the project $[22,23]$.

Despite the benefits, there are still challenges in implementing LPS in construction projects. In the UK, the use of LPS as part of LC implementation is lacking standardization, insufficient knowledge, labourer's comfort zone with the conventional system, lack of training, and lack of coordination [24]. Similar challenges are also found in LPS implementation in projects in Dubai, the UEA, which lacks training, stakeholder's support, and there is less involvement of the project's stakeholders in design, and resistance to change [25].

\section{Research method}

Primary data was obtained from observation, interview, and questionnaire. For this early investigation, there were 4 respondents working for three different government-owned contractors and a private construction management consultant. They have $30,10,8$, and 10 years of project experience, respectively, mainly as project/site managers. The questionnaire for this research was developed from LPS guidebook to determine criteria of practitioner's readiness towards LPS $[4,7,19]$, upon which 50 questions were developed, as shown in table 2 . The questionnaire basically asks how the respondents perceive the LPS principles for their projects to reflect their readiness for LPS implementation.

The answer to each question was categorized into 4 categories, i.e. not aware (NA), aware (A), willing (W), and implemented (I). Each of these categories is worth 0, 1, 2, 3, respectively. The questionnaire also asks the respondents to identify challenges if they implement LPS in their projects. The calculation for readiness assessment was done using the following formulas:

$$
\begin{aligned}
& R S_{(i)}=\frac{T S_{(i)}}{\operatorname{TSmax}_{(i)}} \times 100 \% \\
& T S R_{(i)}=\frac{1}{n} \sum_{i=1}^{n} R S_{(i)}+R S_{(i+1)}+\cdots+R S_{(n)} \\
& O S R=\frac{1}{n} \sum_{i=1}^{n} \operatorname{TSR}_{(i)}+\operatorname{TSR}_{(i+1)}+\cdots+\operatorname{TSR}_{(n)}
\end{aligned}
$$


where: $\mathrm{RS}_{(i)}=$ Readiness Score per element; $\mathrm{TS}_{(i)}=$ Total Score per element; $\mathrm{TSmax}_{(i)}=$ Total Maximum score per element; $\operatorname{TSR}_{(i)}=$ Total Readiness Score of Project; OSR =Overall Score of Readiness

The results of readiness assessment (in percentage) are classified into five levels, i.e. none $(0 \leq \mathrm{x}<25)$, poor $(25 \leq \mathrm{x}<50)$, moderate $(50 \leq \mathrm{x}<75)$, high $(75 \leq \mathrm{x}<100)$, and excellent (100). 100 is set as the top point considering that all elements of LPS are already implemented [13].

\section{Results and discussions}

Tables 2 and 3 show the readiness assessments of the contractors towards LPS implementation. It can be seen that the average score (TSR) for company A, B, C, and D are $68 \%, 66 \%, 83 \%, 71 \%$, respectively. These results suggest that three of them fall into the moderate level, and one high level of LPS readiness. The overall score of readiness (OSR) of $72 \%$ indicates a moderate level of readiness in LPS implementation.

Among other elements, the lowest readiness score is for pull planning element ( $\mathrm{TS}=56 \%$ ), suggesting problems in developing a reliable phased schedule due to a lack of ability in determining the activities' duration and hand off's criteria of satisfaction. The phased schedules also were not developed collaboratively, which could mean a lack of control on work quality. Pull technique has not been used, while the conventional methods based on supply were used instead. MWRP with readiness score $(\mathrm{TS}=64 \%$ ) indicates some weaknesses, e.g. no review on activities based on quality assignment, no constraint log and first run studies to identify each problem of activities on the first 6 weeks, lack of awareness of look-ahead plan. Although master planning and learning readiness scores are considered high $(\mathrm{TS}=81 \%$ and $82 \%$ ), and WWP is considered moderate (TS=75\%), some indicators were still not sufficiently implemented, e.g. no safe workflow in WWP, no daily coordination and evaluation, not detailed activities, no adjusting WWP to labour's capacity, and lack of capacity to explain start and finish of project in front-end planning. Figure 2 visualises the readiness of LPS implementation for each element per company in a form of a spider web diagram.

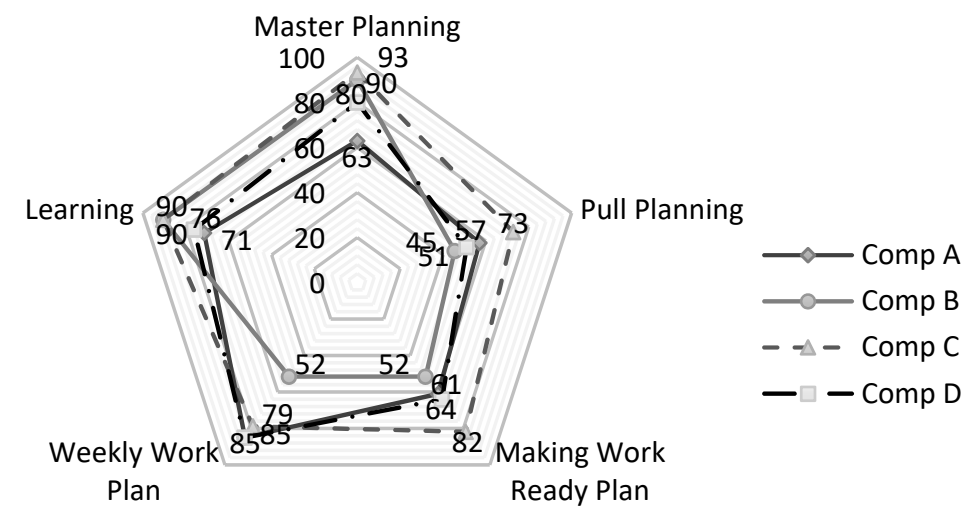

Fig. 2. Spiderweb of readiness score

These results demonstrate that in general, the respondents are not fully ready to implement LPS, particularly for pull planning and MWRP. WWP and PPC are not reliable if the look-ahead plan (MWRP) is not carried out well, because LPS helps to increase the reliability of WWP by properly connecting master or phased schedule through the look- 
ahead plan $[27,28]$. To enable a proper look-ahead plan, information gathering from a range of sources, including the subcontractors is needed [26]. This, however, can become an issue for many construction projects in Indonesia, as the project stakeholders may not get used to being open in sharing information with each other.

Table 2. Assessments of LPS readiness

\begin{tabular}{|c|c|c|c|c|c|c|}
\hline \multirow{2}{*}{$\begin{array}{c}\text { Ele } \\
\cdot\end{array}$} & \multirow{2}{*}{ Ind. } & \multirow{2}{*}{ Question } & \multicolumn{4}{|c|}{ Project } \\
\hline & & & $\mathbf{A}$ & B & $\mathbf{C}$ & D \\
\hline \multirow{10}{*}{ 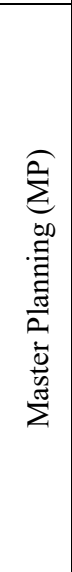 } & \multirow{3}{*}{ Milestone } & Milestone in front-end planning & I & W & I & I \\
\hline & & $\begin{array}{l}\text { Milestones are understood by stakeholders of } \\
\text { project }\end{array}$ & NA & $\mathrm{W}$ & I & I \\
\hline & & $\begin{array}{l}\text { Milestones are understood and aware by } \\
\text { owner }\end{array}$ & $\mathrm{A}$ & $\mathrm{W}$ & I & A \\
\hline & \multirow{4}{*}{$\begin{array}{c}\text { Master } \\
\text { Schedule (MS) }\end{array}$} & Master Schedule is based on milestones & $\mathrm{I}$ & $\mathrm{I}$ & $\mathrm{I}$ & I \\
\hline & & $\begin{array}{l}\text { Master schedule explains start and finish of } \\
\text { project }\end{array}$ & I & I & $\mathrm{W}$ & $\mathrm{W}$ \\
\hline & & $\begin{array}{l}\text { Master Schedule is based on function, area, } \\
\text { and product }\end{array}$ & NA & I & I & I \\
\hline & & Master schedule in only initial plan & NA & $\mathrm{I}$ & $\mathrm{I}$ & $\mathrm{W}$ \\
\hline & \multirow{3}{*}{$\begin{array}{l}\text { Establishes } \\
\text { Promises }\end{array}$} & $\begin{array}{l}\text { Determining target of completion in master } \\
\text { schedule }\end{array}$ & I & I & I & I \\
\hline & & Owner knows about target of completion & I & I & I & $\mathrm{W}$ \\
\hline & & Target is looked as commitment & I & I & $\mathrm{W}$ & $\mathrm{W}$ \\
\hline \multirow{11}{*}{ 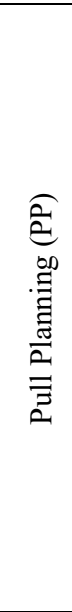 } & \multirow{4}{*}{$\begin{array}{c}\text { Phased } \\
\text { Schedule (PS) }\end{array}$} & Detailing milestone in master schedule & $\mathrm{I}$ & $\mathrm{W}$ & $\mathrm{A}$ & $\mathrm{W}$ \\
\hline & & Pull Technique & $\mathrm{W}$ & NA & $\mathrm{A}$ & NA \\
\hline & & $\begin{array}{l}\text { Usage of sticky notes in making of phase } \\
\text { schedule }\end{array}$ & A & $\mathrm{W}$ & NA & A \\
\hline & & $\begin{array}{l}\text { Determining duration of each phased } \\
\text { activities }\end{array}$ & A & I & I & A \\
\hline & \multirow{3}{*}{$\begin{array}{l}\text { Collaborative } \\
\text { Built Plan }\end{array}$} & $\begin{array}{l}\text { Phase Schedule is attended by all } \\
\text { stakeholders of project }\end{array}$ & I & A & I & $\mathrm{W}$ \\
\hline & & $\begin{array}{l}\text { Phase Schedule is commitment of project's } \\
\text { stakeholders }\end{array}$ & I & A & I & $\mathrm{W}$ \\
\hline & & Being open to each of stakeholders in project & A & $\mathrm{A}$ & $\mathrm{I}$ & A \\
\hline & \multirow{4}{*}{$\begin{array}{c}\text { Focus On } \\
\text { Handoff }\end{array}$} & Knowing handoff's criteria of satisfaction & A & NA & $\mathrm{W}$ & I \\
\hline & & Handoffs is known by project's stakeholders & $\mathrm{I}$ & NA & $\mathrm{W}$ & $\mathrm{W}$ \\
\hline & & Labors know activity's start and finish & NA & I & $\mathrm{I}$ & $\mathrm{W}$ \\
\hline & & $\begin{array}{l}\text { Eliminating buffer time by pressing the } \\
\text { duration }\end{array}$ & A & $\mathrm{W}$ & I & A \\
\hline \multirow{11}{*}{ 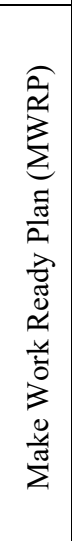 } & \multirow{7}{*}{$\begin{array}{l}\text { Lookahead } \\
\text { Plan (LAP) }\end{array}$} & Developing Lookahead Planning & $\mathrm{A}$ & $\mathrm{W}$ & NA & NA \\
\hline & & Prioritized activities in 4-6 weeks schedule & $\mathrm{I}$ & $\mathrm{I}$ & $\mathrm{I}$ & $\mathrm{I}$ \\
\hline & & Activities is done based on readiness & I & I & I & $\mathrm{W}$ \\
\hline & & $\begin{array}{l}\text { Labors understand about workflow of } \\
\text { lookahead plan }\end{array}$ & NA & NA & NA & NA \\
\hline & & $\begin{array}{l}\text { Determining activities that can and will be } \\
\text { done }\end{array}$ & I & A & I & $\mathrm{W}$ \\
\hline & & Focusing on milestone that was promised & $\mathrm{I}$ & A & I & $\mathrm{W}$ \\
\hline & & Identifying and removing constraints & A & I & I & I \\
\hline & \multirow{4}{*}{$\begin{array}{c}\text { Making Work } \\
\text { Ready }\end{array}$} & $\begin{array}{l}\text { Reviewing activities based on Quality } \\
\text { Assignments }\end{array}$ & A & W & I & I \\
\hline & & Identifying every problems in activities & $\mathrm{W}$ & $\mathrm{W}$ & I & A \\
\hline & & Constraint Log & $\mathrm{W}$ & NA & I & $\mathrm{W}$ \\
\hline & & First Run Studies & $\mathrm{A}$ & NA & I & I \\
\hline
\end{tabular}




\begin{tabular}{|c|c|c|c|c|c|c|}
\hline \multirow{2}{*}{$\begin{array}{c}\text { Ele } \\
\cdot\end{array}$} & \multirow{2}{*}{ Ind. } & \multirow{2}{*}{ Question } & \multicolumn{4}{|c|}{ Project } \\
\hline & & & $\mathbf{A}$ & B & $\mathbf{C}$ & D \\
\hline \multirow{11}{*}{ 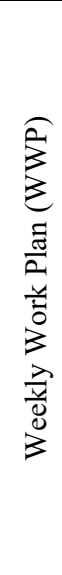 } & \multirow{6}{*}{ WWP } & Developing Weakly Work Plan & I & I & $\mathrm{I}$ & $\mathrm{I}$ \\
\hline & & $\begin{array}{l}\text { Determining activities that will be done in } \\
\text { WWP }\end{array}$ & I & A & I & I \\
\hline & & $\begin{array}{l}\text { Determining requirement to complete } \\
\text { activities }\end{array}$ & I & A & I & $\mathrm{W}$ \\
\hline & & $\begin{array}{l}\text { Setting duration and time of activities in } \\
\text { WWP }\end{array}$ & I & A & A & $\mathrm{W}$ \\
\hline & & Detailing work into activities & $\mathrm{W}$ & A & A & A \\
\hline & & Analysing problem while WWP is running & I & A & I & I \\
\hline & \multirow{5}{*}{$\begin{array}{l}\text { Reliable } \\
\text { Promise }\end{array}$} & Design WWP based on activities can be done & I & $\mathrm{W}$ & I & I \\
\hline & & Developing WWP based on priority & I & $\mathrm{W}$ & $\mathrm{I}$ & I \\
\hline & & Adjusting WWP to labor's capacity & $\mathrm{W}$ & $\mathrm{W}$ & $\mathrm{A}$ & $\mathrm{I}$ \\
\hline & & $\begin{array}{l}\text { Contactor's open to owner about actual } \\
\text { problem }\end{array}$ & W & $\mathrm{W}$ & I & I \\
\hline & & WWP determines the safest workflow & A & A & $\mathrm{W}$ & $\mathrm{W}$ \\
\hline \multirow{7}{*}{ 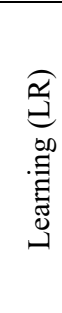 } & \multirow{2}{*}{ Daily Huddle } & Briefing of activities & $\mathrm{W}$ & $\mathrm{W}$ & $\mathrm{W}$ & $\mathrm{W}$ \\
\hline & & Evaluating activities & W & $\mathrm{I}$ & $\mathrm{W}$ & $\mathrm{A}$ \\
\hline & \multirow[b]{2}{*}{ PPC } & Review completion of WWP in percentage & $\mathrm{A}$ & I & I & $\mathrm{W}$ \\
\hline & & $\begin{array}{l}\text { Constraint Analysis dan Productivity } \\
\text { Analysis }\end{array}$ & A & I & I & I \\
\hline & \multirow{3}{*}{$\begin{array}{c}\text { Rapid } \\
\text { Learning }\end{array}$} & Change workflow when problem occurred & $\mathrm{I}$ & $\mathrm{W}$ & $\mathrm{I}$ & $\mathrm{I}$ \\
\hline & & Learning from mistakes & I & I & I & I \\
\hline & & Commitment of Improvement & I & I & I & $\mathrm{W}$ \\
\hline
\end{tabular}

Table 3. Summary of LPS readiness

\begin{tabular}{|c|c|c|c|c|c|}
\hline \multicolumn{2}{|c|}{ Readiness Level (\%) } & Total \\
\hline Element & A & B & C & D & $\begin{array}{c}\text { (\%ore (TS) } \\
\text { Scon }\end{array}$ \\
\hline $\begin{array}{c}\text { Master Planning } \\
\text { (MP) }\end{array}$ & $\begin{array}{c}63 \% \\
\text { Moderate }\end{array}$ & $\begin{array}{c}90 \% \\
\text { High }\end{array}$ & $\begin{array}{c}90 \% \\
\text { High }\end{array}$ & $\begin{array}{c}\text { High } \\
\text { High }\end{array}$ \\
\hline $\begin{array}{c}\text { Pull Planning } \\
\text { (PP) }\end{array}$ & $58 \%$ & $45 \%$ & $73 \%$ & $51 \%$ & $56 \%$ \\
Moderate & Poor & Moderate & Moderate & Moderate \\
\hline $\begin{array}{c}\text { Make Work } \\
\text { Ready Plan } \\
\text { (MWRP) }\end{array}$ & $61 \%$ & $51 \%$ & $82 \%$ & $64 \%$ & $64 \%$ \\
\hline Weekly Work & $85 \%$ & $51 \%$ & $79 \%$ & $85 \%$ & $75 \%$ \\
Plan (WWP) & High & Moderate & High & High & High \\
\hline Learning (LR) & $71 \%$ & $90 \%$ & $90 \%$ & $76 \%$ & $82 \%$ \\
& Moderate & High & High & High & High \\
\hline Total Score of & $68 \%$ & $66 \%$ & $83 \%$ & $71 \%$ & $72 \%$ \\
Readiness (TSR) & Moderate & Moderate & High & Moderate & Moderate \\
\hline
\end{tabular}

Tables 2 and 3 show that some indicators of LPS actually have been implemented in the projects. However, there are challenges of LPS implementation in Indonesia as identified in table 4 for each element, as follows. Challenges in terms of master planning are mainly related to lack of understanding, experience, motivation, and capacity to make a reliable master schedule. Collaboration is the main issue for pull planning which is not common in current practice. Challenges related to MWRP include a lack of understanding of MWRP, no use of look-ahead plan and no constraint analysis. Other challenges for 
WWP and learning include there is no significant difference between WWP and phased schedule and no daily huddle.

Table 4. Challenges of LPS implementation

\begin{tabular}{|c|c|c|c|}
\hline ELEMENT & CHALLENGES & ELEMENT & CHALLENGES \\
\hline $\begin{array}{l}\text { Master } \\
\text { schedule }\end{array}$ & $\begin{array}{l}\text { - Lack of understanding, } \\
\text { experience and motivation } \\
\text { - Lack of transparency } \\
\text { - Undisciplined }\end{array}$ & $\begin{array}{l}\text { Pull } \\
\text { Planning }\end{array}$ & $\begin{array}{l}\text { - Negative perspective towards LPS } \\
\text { - Lack of confidence and motivation } \\
\text { - Lack of honesty }\end{array}$ \\
\hline MWRP & $\begin{array}{l}\text { - Lack of literature about LPS } \\
\text { - Lack of initiative } \\
\text { - Considered as extra job and } \\
\text { waste of time }\end{array}$ & WWP & $\begin{array}{l}\text { - Trust issue } \\
\text { - Owner's mind is business oriented } \\
\text { - Not too thorough and too hasty } \\
\text { - Lack of initiative and motivation }\end{array}$ \\
\hline Learning & $\begin{array}{l}\text { - Lack of initiative } \\
\text { - Too lenient towards delay }\end{array}$ & \multicolumn{2}{|c|}{$\begin{array}{l}\text { - Lack of Commitment } \\
\text { - Lack of Understanding }\end{array}$} \\
\hline
\end{tabular}

In addition, all respondents said that actually, they were keen to implement LPS for their projects in the near future. However, one of the main issues of implementing LPS is the owner's mindset focusing on the result instead of the process, which later causes hesitation for LPS implementation as it was considered a waste of time. Other challenges include; resistance to change, lack of support from the senior project manager, and the need for extra financial incentives for employees for implementing a new system such as LPS. Many of these challenges are in line with the findings of previous research, e.g. [25, 29].

\section{Strategic framework for LPS implementation}

Considering abundant potential benefits of LPS, there is a need to develop a strategic framework for a successful LPS implementation in Indonesia's projects as shown in Figure 3. The framework basically involves multistakeholders, i.e. universities, government, contractor and association of contractors, and students. University as the centre of excellent and anagent of change may introduce and promote LPS to students and the government. Students as future project managers have a strategic position as an agent of change to bring innovation for future projects they will involve. Governmentas clients and regulators may be a role model and set a policy to encourage adoption of LPS particularly by contractors for a more efficient and better delivery of public projects. For capacity building of contractors, the government can collaborate with the association of contractors to give a training and certification of LPS to project managers, and encourage them to form communities to share and to learn LPS. This process will be run repeatedly until LPS will be implemented optimally. 


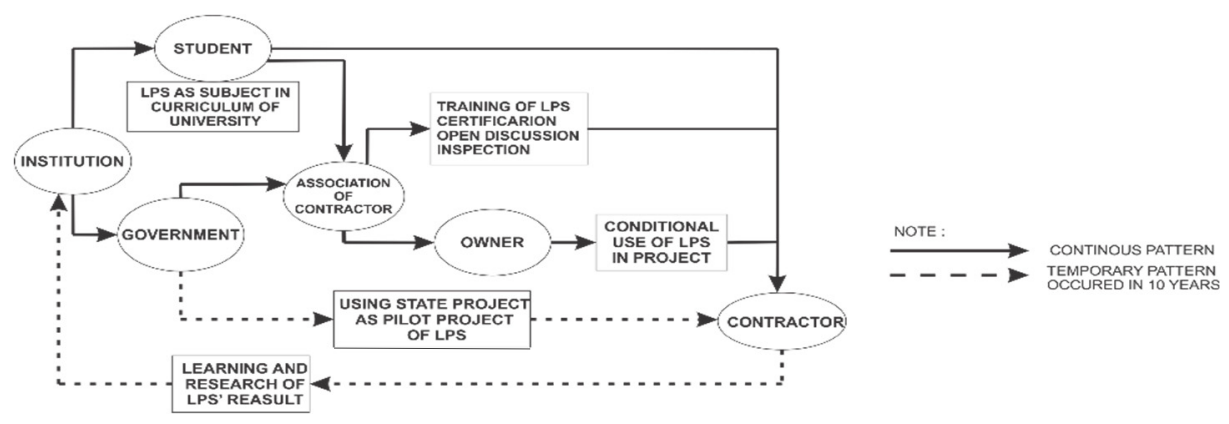

Fig. 3. Implementation Strategy of Last Planner System in Indonesia

\section{Conclusion and recommendation for next research}

This research aims to investigate the readiness of contractors towards LPS implementation. The results show that the total score of readiness (TSR) for company A, B, C, and D are 68\% (moderate level), 66\% (moderate level), 83\% (high level), 71\% (moderate level), respectively, with overall score (OSR) of $72 \%$ (moderate level). This means that actually several elements of LPS have already taken place. Some main challenges of LPS implementation have been identified, such as a lack of understanding and capacity, lack of collaboration among stakeholders, resistance to change, lack of support from the seniorproject manager, the need of extra financial incentives, etc. A strategic framework has also been proposed for a successful LPS implementation in Indonesia's projects. This research is an early investigation of LPS implementation in Indonesia starting with a limited number of respondents, therefore next research can be carried out with a larger number and wider background of respondents.

This research was financially supported by The Faculty of Engineering, Diponegoro University, Indonesia through Strategic Research Grant 2018.

\section{References}

1 T. Abdelhamid and S. Salem,Int.Work. Innov. Mater. Des. Civ. Infrastruct., no. Dec, pp. 1-25 (2005)

2 I. Adamu and G. Howell, 20th Annu. Conf. Int. Gr. Lean Constr., pp. 1-25 (2012)

3 F. Cerveró-Romero, P. Napolitano, E. Reyes, and L. Teran, Iglc-21, vol. 1, no. 40, pp. 709-718 (2013)

4 G. Ballard and I. Tommelein, Current Process Bechmark for The LPS (California, 2016)

5 H. G. Ballard,J. Chem. Inf. Model., vol. 53, no. 9, pp. 1689-1699 (2000)

6 A. Patel, The Last Planner System For Reliable Project Delivery (Texas,2011)

7 I. Tommelein and G. Ballard, The Last Planner Production System Workbook (LCI, California, 2007)

8 A. AlSehaimi, P. Tzortzopoulos, and L. Koskela,17th Annu. Conf. Int. Gr. Lean Constr. IGLC 2009, no. July (2009) (Unpublished)

9 J. L. Fernandez-Solis et al., J. Constr. Eng. Manag., vol. 139, no. 4, pp. 354-360 (2013)

10 Y.-W. Kim and G. Ballard,J. Manag. Eng., vol. 26, no. 4, pp. 223-228 (2010) 
11 A. Mossman,Last Planner (2013)

12 A. Mossman, Last Planner (2009)

13 O. Salem, J. Solomon, A. Genaidy, and M. Luegring, Lean Constr. J., vol. 2, no. 2, pp. $1-21(2005)$

14 W. I. Dharmawan, D. Oktarina, and T. C. Wibowo, vol. 23, no. 1, pp. 59-68 (2017)

15 A. Mossman, Last Planner (2012)

16 B. T. Kalsaas, I. Grindheim, and N. Laeknes, 22nd Annu. Conf. Int. Gr. Lean Constr. Underst. Improv. Proj. Based Prod. IGLC 2014, pp. 639-650 (2014)

17 O. Salem, J. Solomon, A. Genaidy, and I. Minkarah, J. Manag. Eng., vol. 22, no. 4, pp. 168-175 (2006)

18 S. Gao and S. P. Low, Int. J. Proj. Manag.,vol. 32, no. 7, pp. 1260-1272 (2014)

19 R. Davidson,Last Planner System: Business Process Standard and Guidelines(2015)

20 S. Kemmer, L. Koskela, and S. Sapountzis, HaCIRIC 11 Conf. Proc., pp. 1-11 (2011)

21 J. G. Sarhan, B. Xia, S. Fawzia, and A. Karim, Constr. Econ. Build., vol. 17, no. 1, p. 46 (2017)

22 T. Castillo, L. F. Alarcón, and J. L. Salvatierra, J. Constr. Eng. Manag., vol. 144, no. 3, pp. 1-10 (2018)

23 S. Ghosh, D. E. Dickerson, and T. Mills,Int. J. Constr. Educ. Res., vol. 0, no. 0, pp. 118 (2017)

24 A. Tezel, L. Koskela, and Z. Aziz, Prod. Plan. Control,vol. 29, no. 3, pp. 247-269 (2018)

25 E. P. Small, K. Al, and H. Al, Examination of Opportunities for Integration of Lean Principles in Construction in Dubai (CCC, Primosten, 2017)

26 E. Johansen and G. Porter, 11th Annu. Conf. Int. Gr. Lean Constr., vol. 24, no. August, pp. 23-35 (2003)

27 F. Hamzeh and O. Z. Aridi, Modeling The Last Planner System Metrics : A Case Study of An AEC Company (IGLC-21, Fortaleza,2013)

28 F. Hamzeh, G. Ballard, and I. D. Tommelein, Lean Constr. J., pp. 15-34 (2012)

29 V. Porwal, J. L. Fernandez-Solis, S. Lavy, and Z. K. Rybkowski, no. July, pp. 548-556 (2010) 